\title{
Comparison of infectious haematopoietic necrosis virus (IHNV) isolation on monolayers and in suspended cells
}

\author{
P. Hostnik*, V. Jenčič \\ Veterinary Faculty, Gerbiceva 60, 1000 Ljubljana, Slovenia
}

\begin{abstract}
A cell culture virus isolation procedure for infectious haematopoietic necrosis virus (IHNV) in the epithelioma papulosum cyprini cell line (EPC) is described. Ovarian fluid samples were collected from fish and tested for IHNV at 9 farms. The samples were inoculated in parallel on $24 \mathrm{~h}$ old EPC cell monolayers and in freshly trypsinized cells. The titre of the initial virus isolation and of first passages were compared using the 2 methods for each sample. Titres were consistently higher in suspended cells and this method also proved more sensitive for isolation of IHN virus from ovarian fluids of infected fish.
\end{abstract}

KEY WORDS: IHNV $\cdot$ EPC $\cdot$ Susceptibility

Infectious hematopoietic necrosis (IHNV) is a contagious disease of salmonid fish, with a serious economic impact. IHNV affects juvenile fish (Sano et al. 1977). Mortalities from IHNV are higher when other stressors such as low dissolved oxygen, elevated groundwater or low water temperatures are also present (Follett et al. 1987). IHNV has an almost worldwide distribution (Wolf 1988). The virus is present in the liver, kidney, spleen, intestine, gills, brain and ovarian fluid of infected salmonids, from which it can be isolated on cell cultures and identified by immunofluorescence or ELISA tests (O.I.E. 1995).

The virus is a member of the Rhabdoviridae family of the Novirhabdovirus genus (Murphy et al. 1999). The genome incodes 5 proteins: nucleoprotein (N), glycoprotein $(G)$, polymerase $(\mathrm{L})$, phosphoprotein $(\mathrm{P})$ and membrane protein (M). The virus is approximately $170 \mathrm{~nm}$ long and $70 \mathrm{~nm}$ wide (Darlinghton 1972, Wunner \& Peters 1991).

The most frequently used diagnostic method has been the isolation of IHNV in cell culture (Pilcher \&

\footnotetext{
•E-mail: hostnipe@mail.vf.un-lj.si
}

Fryer 1980, Wolf 1988) from ovarian fluid, seminal fluid or tissue samples. It is currently the method of choice for detecting IHNV (O.I.E. 1995) and it is identified by serum neutralisation or immunofluorescent tests (Aurora et al. 1990). In Slovenia, IHNV was first isolated in 1997 from the kidney of moribund salmon and from ovarian fluid during monitoring of salmonid farms for viral diseases. (Jenčič \& Hostnik 1996). Fish infected with the IHN virus are a significant factor for spreading the disease. Since 1990 the number of salmonid fish farms in Slovenia has been increasing rapidly. The development of fish farming has also meant an increase in health problems, the most serious of which is IHNV. To avoid spreading the diseases in Slovenia, all hatcheries are monitored during the hatching period for the presence of viral antigens in ovarian and seminal fluids. Besides an annual surveillance of the salmonid hatcheries, fish in commercial fish farms are observed for clinical signs on a permanent basis. The organs of the fish presumptive to viral diseases are examined for the presence of virus antigens as well.

The present study compares methods for the demonstration of IHNV in ovarian fluid samples inoculated into suspended EPC cells with the standard method of virus isolation on EPC cell monolayers as described in the O.I.E. Diagnostic Manual (1995).

Material and methods. The epithelioma papulosum cyprini (EPC) cell line (Fijan et al. 1983) was kindly provided by G. Bovo, Instituto Zooprofilatico, Padova, Italy, and was used at passage number 253 for the isolation and propagation of IHNV. The cell cultures were mycoplasma tested (Hoechst bisbenzamide fluorochrome and merthiolate dye 33258, Germany) and were found to be negative. Cells were maintained at 20 to $25^{\circ} \mathrm{C}$ in Eagle's minimum essential medium (MEM) and RPMI-1640 medium (Sigma Aldrich CO, UK) mixed in the ratio $1: 1$ and supplemented with $5 \%$ 
fetal bovine serum and $100 \mu \mathrm{g} \mathrm{ml} \mathrm{m}^{-1}$ of the antibiotic garamycin. This cell culture medium was also used as diluent in all viral titrations. Cells were propagated in 96-well microtiter plates for virus isolation. The material in this work (ovarian fluid specimens from salmonids) consisted of 9 pooled samples from rainbow trout Onchorhyncus mykiss and 2 positive reference IHNV strains (IHN virus strain 4008, Bovo et al. [1987] and strain 32/87, obtained from N. J. Olesen, Danish Veterinary Laboratory, Aarhus). Over the winter period, pools (10 fishes) of ovarian fluid were collected from each of 9 trout farms where an IHNV infection had previously been diagnosed. During the time when the samples were collected there were no clinical symptoms of IHNV disease.

Each pool of ovarian fluid samples was diluted and mixed in proportion 1:10 in cell culture medium. The ovarian fluid samples (OFS) were delivered to the laboratory within $24 \mathrm{~h}$ of collection, and the tests were performed immediately. The OFS were centrifuged at $1500 \times g$ for $15 \mathrm{~min}$ and the supernatant filtered through a Millipore membrane filter (pore size $0.45 \mu \mathrm{m}$ ), and divided in 2 aliquots of $1.5 \mathrm{ml}$ each.

Inoculation of OFS on $24 \mathrm{~h}$ old EPC cell monolayers: In U-bottomed multiwell plates (carrier plates) 5 -fold dilutions (12 wells were used) of each test OFS were prepared starting at 1:5. Fifty $\mu$ l of each dilution were transferred to wells in the 96-well plate and incubated $1 \mathrm{~h}$ at $15^{\circ} \mathrm{C}$ on $24 \mathrm{~h}$ old EPC cell monolayers. A reference IHNV strain and a negative control were also included. After adsorption, $100 \mu$ l of cell culture medium were added to each well and incubated at $15^{\circ} \mathrm{C}$ in a moist chamber incubator with $5 \% \mathrm{CO}_{2}$. The cell cultures were examined daily through a microscope (Zeiss, Axiovert 25). If no cytopathic effect CCPE) was observed within $7 \mathrm{~d}$, the samples were passaged onto $24 \mathrm{~h}$ old EPC cell monolayers. If CPE was positive, the identification of virus was performed and the titer of virus was determined.

Inoculation of samples into suspended cell cultures: The EPC cells grown in plastic flasks (Nunclon, Brand Products, Denmark) were trypsinized with $0.25 \%$ trypsin-EDTA (Gibco BRL, Life Technologies, USA). The monolayers were treated with trypsin at $37^{\circ} \mathrm{C}$ for approximately $3 \mathrm{~min}$ and were resuspended in cell culture medium. Fifty $\mu$ l of each sample dilution were transferred from the carrier plates to the cell culture 96-well plates and $50 \mu \mathrm{l}$ cell suspension were added to each well. The number of cells was adjusted to approximately $10^{6}$ cells $\mathrm{ml}^{-1}$. The plates were incubated for $7 \mathrm{~d}$ at $15^{\circ} \mathrm{C}$ in $5 \% \mathrm{CO}_{2}$ atmosphere and were examined microscopically for CPE daily. The end-point virus titers were calculated by the Reed Muench (1938) method with the final reading for CPE being made after 7 th day of incubation.
The virus was identified using an indirect immunofluorescense test. The infected EPC cell culture monolayers in the microtitre plates were fixed for $20 \mathrm{~min}$ in $85 \%$ acetone at $-15^{\circ} \mathrm{C}$. Commercial monoclonal antibodies against the $\mathrm{N}$ protein of IHNV (Biox, Denmark) were used. The monoclonal antibodies $\left(50 \mu \mathrm{lwell}^{-1}\right)$ at a dilution of $1: 40$ were incubated for $60 \mathrm{~min}$ at $37^{\circ} \mathrm{C}$ on the fixed cell layer. The plates were washed 3 times in phosphate-buffered saline (PBS, pH 7.2), and $50 \mu \mathrm{l}$ of fluorochrome isothiocyanate (FITC) conjugated rabbit anti-mouse IgG (Dako) diluted 1:50 were added to each well. After a $1 \mathrm{~h}$ incubation period at $37^{\circ} \mathrm{C}$, the plates were washed again with PBS and the results determined with an inverted fluorescence microscope (Zeiss, Axiovert 25, Germany).

Results. The titers of IHNV in field and reference IHNV samples obtained by inoculation of OFS on cell monolayers and in cell suspensions are shown in Tabie 1. Infection of suspended cells resulted in an apparent increase in IHNV titer by as much as 10 -fold. In addition, CPE production by IHNV and the endpoint of virus titer were substantially quicker. This indicated that the assay could be shortened by 2 to $3 \mathrm{~d}$ using inoculation of samples into suspended cells. Nine samples inoculated into cell suspensions were positive, but only 7 inoculated onto monolayers were positve in primary isolation attempts. Two negative samples became positive after subcultivation. In the case where the field samples were inoculated into freshly trypsinized EPC cells, the median titer after primary inoculation was $9.0 \times 10^{2} \mathrm{TCID}_{50} / 50 \mu \mathrm{l}$; after first passage it was $9.7 \times 10^{5} \operatorname{TCID}_{50} / 50 \mu l$. The median titer of the samples in primary inoculation on cell monolayers was $8.5 \times 10^{1} \mathrm{TCID}_{50} / 50 \mu$ and $5.7 \times$

Table 1. Titration results for $9 \mathrm{IHNV}$ isolates inoculated onto EPC cell monolayers or into EPC cell suspensions

\begin{tabular}{|c|c|c|c|c|}
\hline \multirow[t]{3}{*}{ Sample } & \multicolumn{4}{|c|}{ End-point titers $\left(\mathrm{TCID}_{50} / 50 \mu \mathrm{l}\right)$} \\
\hline & \multicolumn{2}{|c|}{$\begin{array}{l}\text { Inoculation on } \\
\text { monolayer }\end{array}$} & \multicolumn{2}{|c|}{$\begin{array}{l}\text { Inoculation in } \\
\text { cell suspension }\end{array}$} \\
\hline & Isolation & First passage & Isolation & First passage \\
\hline 1 & $1.1 \times 10^{2}$ & $0.2 \times 10^{5}$ & $6.7 \times 10^{3}$ & $3.3 \times 10^{6}$ \\
\hline 2 & $4.3 \times 10^{1}$ & $8.1 \times 10^{4}$ & $1.1 \times 10^{2}$ & $5.2 \times 10^{5}$ \\
\hline 3 & $7.5 \times 10^{2}$ & $7.1 \times 10^{4}$ & $0.1 \times 10^{3}$ & $3.4 \times 10^{6}$ \\
\hline 4 & Negative & $8.0 \times 10^{3}$ & $5.9 \times 10^{1}$ & $0.3 \times 10^{4}$ \\
\hline 5 & $8.3 \times 10^{2}$ & $2.2 \times 10^{5}$ & $5.1 \times 10^{2}$ & $8.2 \times 10^{5}$ \\
\hline 6 & $8.2 \times 10^{0}$ & $8.1 \times 10^{4}$ & $6.7 \times 10^{3}$ & $5.6 \times 10^{5}$ \\
\hline 7 & $8.5 \times 10^{1}$ & $0.2 \times 10^{4}$ & $0.3 \times 10^{3}$ & $0.8 \times 10^{5}$ \\
\hline 8 & $0.4 \times 10^{2}$ & $3.0 \times 10^{5}$ & $9.1 \times 10^{2}$ & $0.1 \times 10^{5}$ \\
\hline 9 & Negative & $2.5 \times 10^{3}$ & $0.2 \times 10^{1}$ & $6.5 \times 10^{4}$ \\
\hline IHNV ${ }^{a}$ & $4.3 \times 10^{5}$ & & $6.2 \times 10^{6}$ & \\
\hline $\mathrm{IHNV}^{\mathrm{b}}$ & $2.6 \times 10^{5}$ & & $4.2 \times 10^{6}$ & \\
\hline \multicolumn{5}{|c|}{$\begin{array}{l}\text { a Strain 4008, Passage 5th; Bovo et al. (1987) } \\
\text { 'Strain 32/87, Passage } 7 \text { th; Hattenberger-Baudouy et al. } \\
\text { (1989) }\end{array}$} \\
\hline
\end{tabular}


$10^{4} \mathrm{TCID}_{50} / 50 \mu \mathrm{l}$ after 1 passage. Using suspended cells, the virus titer was $10 \times$ higher after primary inoculation and $10.4 \times$ higher after first passage. IHNV strain 4008 gave $14.4 \times$ and strain $32 / 87$ gave $16.2 \times$ higher titers when inoculated onto suspended cells. The parallel titrations of IHNV reference strains provided on EPC cell monolayer and into freshly trypsinized cell suspension gave results similar to those obtained using field IHNV isolates. The virus titer was higher when the virus was inoculated into freshly trypsinized cell suspension. Using indirect immunofluorescence tests all 9 isolates were identified as IHN virus.

Discussion. This paper describes the comparison of the susceptibilities of EPC cells to IHNV when samples were inoculated onto cell suspension immediately after trypsinization and onto $24 \mathrm{~h}$ old EPC cell monolayers. The data indicate that freshly trypsinized EPC cells are more sensitive for the isolation of IHNV than $24 \mathrm{~h}$ old EPC cell monolayers. The sensitivity of isolation assay for IHNV was significantly improved by inoculation of samples into suspended EPC cells instead of into $24 \mathrm{~h}$ old cell cultures. The titre of IHNV increased with the passage in the EPC cells. For isolation of IHNV many authors have reported that the EPC cell line was the most sensitive and generally gave the highest titers (Yoshimizu et al. 1988). Results of inter-laboratory comparision of susceptibility of different cell lines to IHNV also showed that EPC cells gave the best results. The samples were inoculated onto cell monolayers not more than 24 h old (Lorenzen et al. 1999) The virus isolation success rate from IHNV-infected OFS was higher using the cell suspension method than using the standard method of inoculation of samples into monolayers as described in the OIE manual. EPC cells are usually grown at 20 to $25^{\circ} \mathrm{C}$ (Fijan et al. 1983). The successful growth and propagation of EPC cells at $15^{\circ} \mathrm{C}$ was better when the cell culture medium MEM was supplemented with RPMI-1640 medium (Sigma Aldrich Co, UK). In this growth medium EPC cells multiply at $15^{\circ} \mathrm{C}$, which is needed for IHNV propagation. Preliminary experiments presented in this study also indicate that rapidly growing EPC cell cultures are more susceptible to virus infection than confluent cultures. Based on these results, it is concluded that more IHN cases would be detected if the specimens previously diluted serially were inoculated into freshly trypsinized cells and incubated at $15^{\circ} \mathrm{C}$.

The reduction in virus susceptibility of cell cultures previously treated by trypsin has been described. More intensive trypsinization can remove various glycopeptide responsible for the attachment of the virus to the cell membranes (Geartner et al. 1991). Results of this work show that a short treatment of EPC cell monolayers at room temperature with a TrypsinEDTA (Gibco) solution caused no reduction in suscep- tibility of EPC to IHNV infection. Long-term exposure of cells to trypsin could damage protein $G$ receptors that are responsible for binding the virus on the cell. This causes decresed binding of virus on the cell.

A few workers have used polythylene glycol (PEG) to increase the IHNV titer. Cells were pretreated with $7 \%$ PEG for $30 \mathrm{~min}$ before virus was added, resulting in titers 10 -fold or higher over that abstaince with untreated cells. (Batts \& Winton 1989).

From these results we conclude that the inoculation of samples into cell suspensions is a more sensitive method for IHNV isolation than inoculation onto $24 \mathrm{~h}$ old monolayers of EPC cells. It was found that the classical inoculation method on cell monolayers was not as appropriate for detecting small amounts of IHNV antigen as inoculation into EPC cell suspensions. We recommend its use to obtain a more accurate picture of the IHNV infection status of salmonid farms.

Acknowledgements. We are grateful to Dr Ellen Ariel for constructive comments on the manuscript.

\section{LITERATURE CITED}

Aurora LB, Lupiani B, Dopazo CP, Toranzo JL (1990) Fish viral infections in northwest of Spain. Microbiologija Sem 6: 21-29

Batts WN, Winton JR ( 1989 ) Enhanced detection of infectious hematopoietic necrosis virus and other fish viruses by pretreatment of cell monolayers with polyethylene glycol. J Aquat Anim Health 1:284-290

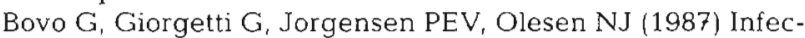
tious haematopoietic necrosis: first detection in Italy. Bull Eur Assoc Fish Pathol 7:117

Darlington RW. Traford R, Wolf K (1972) Fish rhabdoviruses: morphology and ultrastructure of North American salmonid isolates. Arch Ges Virusforsch 39:257-264

Fijan N, Sulimanovic D, Bearrzoti M, Muzinic D, Zwillenberg LO, Chilmonczyk S, Vautherot JF, De Kinkelin P (1983) Some properties of the epithelioma papulosum cyprini (EPC) cell line from carp (Cyprinus caprio). Ann Virol (Inst Pasteur) 134E:207-220

Follett JE, Thomas JB, Hauck AK (1987) Infectious haematopoietic necrosis virus in moribund and dead juvenile chum, Oncorhynchus keta (Walbaum) and chinook, $O$. tshawytscha (Walbaum) salmon and spawing adult chum salmon at an Alaskan hatchery. J Fish Dis 10:309-313

Geartner DJ, Smith AL, Paturzo FX, Jacoby RO (1991) Susceptibility of rodent cell lines to rat coronaviruses and differential enhancement by trypsin or DEAE-dextran. Arch Virol 118:57--66

Hattenberger-Baudouy AM, Danton M, Merle G, Torchy C, de Kinkelin P (1989) Serological evidence of infectious hematopoietic necrosis in rainbow trout from a French outbreak of disease. J Aquat Anim Health 1:126-134

Jenčič V, Hostnik P (1996). Viral haemorrhagic septicaemia of salmonids the influence of different storage conditions on the ELISA test. Bull Eur Assoc Fish Pathol 16(2):43

Lorenzen E, Carstensen B, Olesen NJ (1999) Inter-laboratory comparison of cell line for susceptibility to three viruses: VHSV, IHNV and IPNV. Dis Aquat Org 37:81-88 
Murphy FA, Gibbs EPJ, Horzinek MC, Studdert MJ (1999) Rhabdoviridae. In: Veterinary virology, Chap 27. Academic Press, San Diego, p 429-445

O.l.E. (1995) Diagnostic manual for aquatic animal diseases, 1 st edn. Office International des Epizooties, Paris, p 31--43

Pilcher KS, Fryer JL (1980) The viral diseases of fish: a review through 1978. Part I: diseases of proven viral etiology. Crit Rev Microbiol 7:287-364

Reed LJ, Münch H (1938) A simple method for estimating fifty per cent end-points. Am J Hyg 27:493-497

Sano $T$, Nishimura $T$, Okamoto $N$, Yamazaki $T$, Hanada $H$ (1977) Studies on viral diseases of Japanese fishes. VI.

Editorial responsibility: Jo-Ann Leong,

Corvallis, Oregon, USA
Infectious hematopoietic necrosis (IHN) of salmonids in the mainland of Japan. J Tokyo Univ Fish 63:81-85

Wolf $K(1988)$ Fish viruses and viral diseases. Cornell University Press, Ithaca, New York, p 83-113

Wunner WH, Peters D (1991) Family Rhabdoviridae. In: Francki RI, Fauque CM, Knudson DL, Brown F (eds) Classification and nomenclature of viruses. Archives of Virology, Suppl 2, Springer, New York, p 250-262

Yoshimizu M, Kamei M, Dirakbusarakom S, Kimura T (1988) Fish cell lines: susceptibility of salmonid viruses. In: Kuroda Y, Kurstak E, Maramorosch K (eds) Invertebrate and fish tissue culture. Springer-Verlag, Berlin, p 207-210

Submitted: August 9, 1999; Accepted: February 10, 2000 Proofs received from author(s): March 20, 2000 